\title{
The Reasons of Conflicts in the Relationships between Parents and Children
}

\section{Причини конфліктів у взаємостосунках між батьками та дітьми}

\author{
Iryna Kompliienko \\ State institution «Center for Mental Health and Monitoring \\ of Drugs and Alcohol of Ministry of Health of Ukraine», Kyiv \\ (Ukraine) \\ ORCID ID: https://orcid.org/0000-0001-5007-8779 \\ Researcher ID: AAL-4652-2020 \\ e-mail: komplienko78@ukr.net

\section{Ірина Комплієнко} \\ Державна установа «Центр психічного здоров'я і моніторин- \\ гу наркотиків та алкоголю Міністерства охорони здоров'я Украї- \\ ни», м. Київ (Україна)
}

\section{ABSTRACT}

The purpose of this article is finding out the problem of maladaptive family relationships between parents and senior schoolchildren which are usually characterized by the severity of conflicts which have being arisen, by blocking of their constructive resolution, the exacerbation of intra-family alienation.

Methods of the research. The following theoretical methods of the research were used to solve the tasks formulated in the article: a categorical method, structural and functional methods, the methods of the analysis, systematization, modeling, generalization. Method of interviewing was used as empirical one.

Address for correspondence, e-mail: kpnu_lab_ps@ukr.net Copyright: (C) Kompliienko Iryna

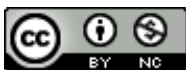


The results of the research. In order to find out the causes of conflicts between senior pupils and their parents we organized a pilot research based on the questionnaire "Reasons of conflicts between senior schoolchildren and their parents» developed by us. The questionnaire was proposed for 355 senior pupils from Kyiv, Rivne and Mykolaiv. From the point of view of youth, conflicts with parents are not the main problem in this age. Based on a survey of a representative group of 16-year-old pupils, about a third part of them (about $27 \%$ of schoolgirls and $29 \%$ of male schoolchildren) found disputes, considerable differences of opinion with parents, rejection of criticism as the reason for conflicts. At the same time, only a few pupils completely reject the views of parents, who are called as "old ones" (8\% of schoolgirls and 13\% of male senior pupils). For $33 \%$ of schoolgirls and $27 \%$ of male schoolchildren, criticism and controversy do not apply to all spheres of their life, but mainly to clothing, hairstyles and evenings at home. Senior pupils who use psychoactive substances have significantly more conflict situations than healthy ones. Disputes with parents are the most important negative factor that hinders the development of senior pupils (35\% of male respondents and $28 \%$ of female). At the same time, $26 \%$ of schoolgirls and $31 \%$ of male pupils suggested that learning problems led to drug use, delinquency, symptoms of stress and low self-esteem.

Conclusions. It is during the period of maladaptation, for example, when the mother and the child are deprived of one of the possibilities of resolving conflict situations, which in a certain period of time were real, such as: facilitating the relationships through the intervention of the third person - an aunt, a grandmother and some others. As a rule, in this case, throughout the subsequent life of the existence of good and loving the third person helps to compensate for the joyless moments that take place in the relationships with the "other one»; this attitude greatly neutralizes the child's aggression and significantly eliminates the emergence of fear. In a family where a child takes psychoactive substances, the conflict with a mother or a father (or both of them) becomes extraordinary. In addition, the child's communication with the father is perceived by the mother as a situation of relief. But if the mother is divorced, then everything becomes much more complicated, and if the child, after arguing with her, suddenly tries to call the father, the mother may get very angry and shout at the child: "Well, go to live with your dad!» Emotionally agitated mothers usually do not understand what they are doing with this phrase, resorting to this kind of method as a struggle is; moreover, the child will feel defeated, and he / she feels a satisfaction - his / her goal has been achieved. At the same time, the child begins to realize that

(C) Kompliienko Iryna

DOI (article): https://doi.org/10.32626/2227-6246.2020-50.104-126 
DOI: https://doi.org/10.32626/2227-6246.2020-50

the mother tells him / her to "get out", and the father is already almost have lost her, and then the mother says that she does not need the child at all. Thus, the child "is cornered", and he / she is in despair experiencing the hopelessness of this situation, feels anger towards the mother. Therefore, it is no coincidence that such children begin to look for another, important for them social microgroup, which leads to dependence on the use of psychoactive substances.

Key words: maladaptive family relationships, conflicts, unconstructive resolution, the exacerbation of intra-family alienation, reasons of conflicts, aggression, fear, psychoactive substances.

\section{Introduction}

In the psychological literature, when we tell about the complexities of family relationships, scientists identify the relationships of parents with their children as the most problematic. In such a way, V. Satyr notes that to be filled with the energy, released from the physiological changes of puberty, characterized by the actual need for independence, filled with expectations of future success in a great life, and that's why senior pupils at secondary school go through great trials in finding their own way in a new world (Сатир, 1992).

Senior school age is characterized as quite complex and contradictory. The most important psychological new formation of senior school age is the feeling of adulthood - it is a special form of self-awareness, which indicates the desire of senior pupils for independence. Children at this age claim equality with their elders, try to reach a special level not only to reach adult control but often to gain assistance (Максименко, Ткач, Литвинчук \& Онуфрієва, 2019).

Depending on the specific social conditions, culture, traditions which usually are in the process of upbringing the children, the requirements for senior pupils in each family of this age period may have different meanings and different forms of their explication (Гарбузов, 1990). No wonder that some researchers connect a special conflict of children with their parents in the senior school age with the fact that during this (C) Kompliienko Iryna

DOI (article): https://doi.org/10.32626/2227-6246.2020-50.104-126 
period there is a revision and reassessment of a younger generation of moral and value ideas; pupils are characterized by increasing depersonalization. The last factor is closely related to the separation of senior pupils from the reference, the most important people for them. Parents play a special role of a model which is increasingly receding into the background, and the values for themselves are becoming increasingly important for themselves (Раттер, 1978).

Thus, pupils feel the "devaluation» of parents as a high moral standard, and they are increasingly relevant to some abstract values. Former loyalty to parents is increasingly being transferred by senior schoolchildren to a peer reference group.

At senior school interpersonal conflicts often take place between parents and children. Some researches define interpersonal conflict as a situation of collision and struggle of independent points of view, interests, attitudes of people, situations, which cause them feelings of deep disagreement, a great emotional experience of dissatisfaction with themselves and other people. Conflicts with relatives are often accompanied by negative emotions and feelings (Стегачёва, 2004).

Other researches believe that in a conflict situation there are always contradictions that are arisen between people in important for them aspects of interpersonal interaction, which violates their relationships with each other, and therefore causes certain actions by the parties according to the conflict to resolve problems which are arisen. Under the «conflict situation" we mean a set of preconditions and life circumstances in which there is a collision of the person with any opposing opinion, which is characterized in relations to a life paradigm of incompatibility of goals and ways to achieve them in a better way. Thus, family conflict is a special form of maladaptive behavior, in which adaptive reactions are ineffective and only exacerbate ones' conflicts (Mykhalchuk \& Onufriieva, 2020).

So, the purpose of the article is finding out the problem of maladaptive family relationships between parents and (c) Kompliienko Iryna

DOI (article): https://doi.org/10.32626/2227-6246.2020-50.104-126 
senior schoolchildren which are usually characterized by the severity of conflicts which have being arisen, by blocking of their constructive resolution, the exacerbation of intra-family alienation.

\section{Methods of the research}

The following theoretical methods of the research were used to solve the tasks formulated in the article: a categorical method, structural and functional methods, the methods of the analysis, systematization, modeling, generalization.

\section{Results and their discussion}

Analyzing the conflicts in the relationships between parents and children, it can be noted that they rarely are accidental and sudden. Nature itself seems to have "taken care» of the mutual attraction of parents and children, providing these relationships with a sense of love and need of each other. But both parents and children often misuse this gift, and it is the problem of their communication and relationships.

It was emphasized that misunderstandings in the relationship between parents and children, their assessments of each other, priorities, lifestyles, etc., often led to conflicts that injure those whom we loved, causing serious mental disorders.

The results of empirical researches emphasize that the situations of conflicts between children and parents, as a rule, take a moral and pedagogical nature and due to a low level of general and pedagogical culture of parents, shortcomings and mistakes of family upbringing, misunderstanding of age and psychological characteristics of this child with other relatives.

Conflicts between parents and senior pupils often take a place in the conditions of the poor performance of children, because children do not understand that education significantly affects their future position in the society or gives a chance to climb up a social ladder. Based on the data of foreign researchers (Сатир, 1992), we conclude that conflicting relationships (C) Kompliienko Iryna

DOI (article): https://doi.org/10.32626/2227-6246.2020-50.104-126 
of pupils with parents are usually found in matters of music, clothing, entertainment, and the alienation between parents and children increases when pupils are in the age of 14-17 years old. Researchers suggest that alienation is largely due to the preservation of schoolchildren's economic dependence on their parents.

In order to find out the causes of conflicts between senior pupils and their parents we organized a pilot research based on the questionnaire «Reasons of conflicts between senior schoolchildren and their parents» developed by us. The questionnaire was proposed for 355 senior pupils from Kyiv, Rivne and Mykolaiv. From the point of view of youth, conflicts with parents are not the main problem in this age. Based on a survey of a representative group of 16-year-old pupils, about a third part of them (about $27 \%$ of schoolgirls and $29 \%$ of male schoolchildren) found disputes, considerable differences of opinion with parents, rejection of criticism as the reason for conflicts. At the same time, only a few pupils completely reject the views of parents, who are called as "old ones» $(8 \%$ of schoolgirls and $13 \%$ of male senior pupils). For $33 \%$ of schoolgirls and $27 \%$ of male schoolchildren, criticism and controversy do not apply to all spheres of their life, but mainly to clothing, hairstyles and evenings at home. Senior pupils who use psychoactive substances have significantly more conflict situations than healthy ones. Disputes with parents are the most important negative factor that hinders the development of senior pupils (35\% of male respondents and $28 \%$ of female). At the same time, $26 \%$ of schoolgirls and $31 \%$ of male pupils suggested that learning problems led to drug use, delinquency, symptoms of stress and low self-esteem.

Conflicts between senior pupils and their parents usually appear as a result of very specific reasons. Thus, approximately $34 \%$ of male and $32 \%$ of female schoolchildren consider that their parents' style of upbringing has to be too restrictive; $30 \%$ of male and $33 \%$ of female respondents believe that

(c) Kompliienko Iryna

DOI (article): https://doi.org/10.32626/2227-6246.2020-50.104-126 
this style is old-fashioned, and only $36 \%$ of male and $35 \%$ of female senior pupils name other reasons for their parents' negative attitude towards them.

Some scientists underlined that the problem of the usage of psychoactive substances is one of the most urgent among other medical and social issues of nowadays in the world in general and in Ukraine. One of the aspects of the threatening nature of this phenomenon, in addition to prevalence, is psychological and somatic consequences, so called comorbid conditions, which lead in the future to severe psychosomatic disorders, more significant for young patients. Contemporary medical reform in Ukraine, based on the world experience of the leading countries in the world, reoriented general medical care of somatic patients to family doctors. This process requires the creation of professional scientific and practical issues for qualified assistance in the complex of treatment of somatic patients (Tabachnikov, Pinchuk, Kharchenko, Osukhovskaya, Tabachnikov, Mazbits, Chepurna, Salden, Tovalovych \& Mykhalchuk, 2018).

Scientists analyzed the results of their research. They proved that in accordance with the relevant methods (clinical, anamnestic, socio-demographic, psycho-diagnostic, clinical-psychopathological and statistical), 220 thematic patients who had applied with somatic complaints to the family doctor had been examined. All these patients take different kinds of psychoactive substances. These patients applied to family doctors during 2017-2019. The number of men was 54\%, women $-46 \%$. Respondents were divided into 2 groups by age: 18-35 years old, 36-60 years old.

The characteristic features of such patients were revealed: prevailed age group was the group with elder people $-62 \%$, the younger group was $38 \%$. However, it should be emphasized that students have to apply to profile clinics if they have some problems with the health. According to the anamnesis, a large proportion of respondents were raised in dysfunctional (c) Kompliienko Iryna

DOI (article): https://doi.org/10.32626/2227-6246.2020-50.104-126 
families $(42 \%)$ : alcohol abuse, divorce or civil parental marriage, systematic conflicts in the families, material problems, burdened heredity, imbalance in the nature of emotional fluctuations of the mother, concomitant somatic illnesses $(28 \%)$. In such a way it is possible to calculate the amount of indicated problems as a probable interconnection with the addictive behavior of respondents who used psychoactive substances. At the same time, the majority of those respondents began to use psychoactive substances (more often alcohol or tobacco) in small or young age $(66 \%)$, much less $(34 \%)$ - in the elderly age. The motivation for the usage of psychoactive substances by respondents, especially young people, is the influence of friends, companies, fashion, contemporary surrounding, the negative microenvironment, the desire for pleasure, the desire to have unusual feelings. At the elder age it is a subjective deprivation or leveling of difficult personal circumstances, mood swings, positive departure from micro- and macro-problems, improving the general mental and physical states. All these problems cause great conflicts between parents and their children (in such a case we have to obtain the situation from two sides. From the first side it is the situation when the parents use psychoactive substances by themselves. From the other side pupils use psychoactive substances) (Tabachnikov, Pinchuk, Kharchenko, Osukhovskaya, Tabachnikov, Mazbits, Chepurna, Salden, Tovalovych \& Mykhalchuk, 2018).

Among the reasons of conflicts with parents, according to senior schoolchildren, the most important of them are: the difference between the acquired personally significant experience of children and adults, first of all - during their adulthood (parents and children differ in many ways, including a view of contemporary realities); the lack of clear, consistent steps from the transition from child's dependence to adult independence; the absence of certain rules for the construction of family relationships which significantly weaken parental power during the transition of children from childhood to adolescence; psy- 
DOI: https://doi.org/10.32626/2227-6246.2020-50 2020. випуск 50 chological and social differences between parents and children; psychologically, it is explicated in the mismatch of young people's attitudes and perceptions and personally meaningful experience of adults, and sociologically - in the paradigm of collision of controlling role of adults with the needs of young people to achieve autonomy; overload and stress as a result of social and cultural changes that affect, in turn, family relationships (Tabachnikov, Pinchuk, Kharchenko, Chepurna, Zdoryk \& Mykhalchuk, 2019).

It was proved that most conflicts had being arisen as a result of tensions, the need for senior schoolchildren to be independent, as well as the awareness of children of their responsibility. The value of independence is often exaggerated by youth for reasons related to the characteristics of the growing up period (the emergence of new opportunities that you want to try under any circumstances). At the same time, parents' sense of responsibility is greatly enhanced in the face of unnecessary fears or as a kind of protection for their own unhappy requests and instructions.

In addition to these reasons we'll also note that due to significant time gaps between senior pupils' achievement of biological maturity and social status children face contradictions that are arisen between their abilities and imaginary psychological characteristics of their persons. In general, the desire of senior schoolchildren has a great aim to achieve individual's independence and autonomy. It was stated that the maladaptive reactions of senior schoolchildren can be universal or directed against the family, as a protest, etc. Often, senior schoolchildren have a reassessment of family values as a result of changing general living conditions, when the individual development of the child's personality does not find social approval and support.

Disadaptive family relationships lead to the deactivation of value-oriented activities: there is no certain classification of any actions except those ones that occur «right» and «bad», (C) Kompliienko Iryna

DOI (article): https://doi.org/10.32626/2227-6246.2020-50.104-126 
«right» and «wrong», "as good as it is possible» and «as bad as it is possible». According to the results of our empirical research, more than $40 \%$ of senior pupils participated in the research in Kyiv and Rivne would like to have more great advice than they have also had, and just over $10 \%$ of respondents believe they have more care than they need. However, the willingness of children to submit their own behavior and activities to understand and to accept so called «parental advice» does not depend so much on the fact that the parents are adults and therefore always right. Whether children listen to their parents' wishes, first of all, on the extent to which children accept the parents' life position, how much they respect them, how much parental values are perceived in such a way that they should be accepted and reproduced with dignity.

But it is usually difficult for parents to meet the requirements of senior pupils, which are put forward by children in the contemporary society, because the values that children focused on before - significantly devalued, and the reorientation onto a new system of values has not yet taken a right place. Thus, there is a "devaluation» of the moral standard of parents. Meanwhile, the demands of adults continue to take a purely directive nature, without trying to explain, consulting with a pupil. The latter creates another contradiction in the communication of schoolchildren with their parents, because the main new formation of adolescence (11-15 years) is the transition to critical thinking. Thus, the teenager differs in his / her desire to think logically. This desire is provided, first of all, in criticism and extreme wishes that the thoughts, demands and aspirations of parents are always proved. A senior pupil constantly demands proof. But as a result of the parents when they are not providing him / her, a so-called semantic barrier arises, when the discrepancy of meaning concerns the content of the requirements, which then becomes a barrier for a certain person (a father or a mother or parents) (Пожар, 1996).

(C) Kompliienko Iryna

DOI (article): https://doi.org/10.32626/2227-6246.2020-50.104-126 
Psychological research emphasizes such an extremely important characteristic of the conflicts of senior pupils with their parents, and more precisely emphasize on the nature of the subjective attitude of the members of the family to participate in conflict situations which have been arisen. The culprit of the conflict is always a child, so parents, teachers and senior pupils themselves believe that this conflict can be solved. Some authors call this attitude of senior pupils as selfblame "psychological reconciliation», linking it to the acceptance of formal «obedience» according to relationships which are imposed on children. Having understood the positions of «psychological reconciliation» which often lead to the personal stage of psychological rebellion, and when this so-called «psychological rebellion» occurs, adults begin to go to a psychologist, looking for a way out, while children's "psychological reconciliation" is quite satisfied. At the same time, such an attitude as conflicts, when adults take a strong position of blaming the child, and senior pupils - a position of self-blaming, and it is extremely unconstructive, and their "removal» is one of the dominant tasks of psychologists, both in conflict resolution and as a result of the organization of educational and psychoprophylactic activity with parents (Mykhalchuk \& Ivashkevych, 2018).

We should also dwell on another point to which researchers rarely pay attention. Adults, at the process of growing up of senior pupils, often notice in this process only the negative aspects - «a child became naughty, secretive», etc., and do not notice positive, new, identical facts, etc. One of such manifestation is the development of empathy of adults, the desire to help them, to support, to share anxiety and joy. To reach the best results, adults are ready to express their sympathy for other pupils, but they are absolutely not ready to accept such an attitude on their participation. This situation deals with, first of all, the fact that parents do not want to accept this attitude of the child, because this is what requires children (C) Kompliienko Iryna

DOI (article): https://doi.org/10.32626/2227-6246.2020-50.104-126 
behavior. Thus, many of the current problems with parenting arise because adults try to do only something for their child and are unwilling and unable to take anything from it. But only through real presentations of kindness, compassion, empathy the important personal qualities can be developed.

Researches of conflict relations of senior pupils with adults concern, first of all, conflicts of children with teachers. A conflict of parents with pupils is considered only in fragments. It should also be noted that at the senior school the age of pupils plays a great role by the need to be a participant of communication, not just a witness of the events that take place, to declare themselves as the most important individuals, to express their own attitudes to the events. Although a pupil does not always clearly imagine these consequences and actions, this need, in turn, activates a number of related needs which are the most specific to this age, which include the following characteristics:

- the need to be able to «do something», and not just go to school, which requires its satisfaction in senior age and is one of the ways of self-expression that can be appreciated by classmates. Such an assessment is more significant for a pupil than the assessment of his / her educational activities, the content of which is not always significant for this schoolchild;

- the need to have a certain value for others, to be needed by someone with all his / her individual qualities, advantages and disadvantages, not to feel "worthless» in the eyes of both adults and classmates;

- the need for self-expression, which explains to senior pupils increased interest and self-respect, the desire to defend their views and protects from aggression by others, but not to show «a tacit agreement» with the situation;

- the characteristic of senior pupils which actualizes the need for equal communication with adults, which is expressed for protest against the mandatory forms of communication with classmates. In response to mandatory forms of interac-

(C) Kompliienko Iryna

DOI (article): https://doi.org/10.32626/2227-6246.2020-50.104-126 
tion, senior pupils, as a rule, do not comply with the requirements of adults, but go into open conflict with them.

Finally, the actualization of gender identity leads to the fact that pupils seek to demonstrate "the male behavior» and girls - «a female one», which is not always approved by adults, and this, in turn, often creates conflict situations.

The explication of complete obedience by a child in senior age is often replaced by the desire to perform some independent active actions, for example, how the child will carry out his / her behavior and implement activities largely depends on what is his / her experience of behavior and communication is the dominant. Taking into account these patterns of mental development of senior pupils, the nature of interaction with them with age becomes much more complicated, the number of conflicts between senior pupils and their parents increases rather significantly.

The number of conflicts is especially high when the whole family is transformed into the incomplete one; then the psychological atmosphere in the family changes qualitatively, children fall into the paradigm of complex psychological problems associated with the absence of a father or a mother in the family. All these aspects will be described in other our researches and articles.

A special problem for children in the case of divorce of their parents we consider in such a reason that the age of adolescences and senior pupils. Even if to look from the side of harmonious family relationships, these age periods are the most difficult test of life due to conflict. We emphasize the danger of family breakdown when children are 12-16 years old. The drama of divorce makes children feel that they are undesirable and not "children of love, but rather they are hatred". In this case, children experience great difficulties in relations according to their personality, they stop loving themselves and do not see the other meaning in their lives and a life way. Such children become aggressive, accuse the mother of taking her (C) Kompliienko Iryna

DOI (article): https://doi.org/10.32626/2227-6246.2020-50.104-126 
father away, and show aggression and disobedience. Relationships between children and parents become largely conflicted, taken on a protracted nature, and, in this case, there is usually no way out of this situation, and senior pupils who are cared for by their parents feel themselves in a great degree unhappy.

Children react quite negatively to their parents' divorce, usually with confusion and fear. The fact is that in children's experiences the image of their parents' divorce is not associated with their divorce, in accordance with each other, but rather as the divorce of one parent from the child. At the same time, as a rule, if a child feels the loss of his / her father, then, at the same time, he / she is afraid of losing his / her mother. In the most cases, children after the divorce of their parents show signs of anger and aggression. The latter are reactions of maladaptation due to them having felt helplessness, confusion and betrayal. Often children ask their parents: «How could you do this for me?» In such situations, a conflicting attitude towards one of the parents is formed. In addition, the child's experience is in a great degree a cognitive dissonance, as, in such a way, there is a struggle between hatred and love, between aggression and the need for feeling a sense of security. Often, due to their rather difficult mental, social and economic situation, as well as the result of considerable physical exertion due to divorce, parents are simply unable to help a child who needs peace, patience and the ability to take care of his / her personal problems. Also in a single-parent family the parent who is left with the child is in a great danger - children will usually see him / her as the enemy who has created a sense of danger for the child. Such a family's crisis after divorce can lead to the loss of positive relationships for a long period of time. The child will constantly make high, unrealistic demands for one of the parents with whom he / she is left to live. In such a situation, the main thing is that the child feels the need of a significant adult, wants his / her life to be full of love and, at the same time, the person is reliable to protect him / her from

(C) Kompliienko Iryna

DOI (article): https://doi.org/10.32626/2227-6246.2020-50.104-126 
DOI: https://doi.org/10.32626/2227-6246.2020-50 2020. ВипУск 50 the dangers that are arisen in the social space. Most mothers cannot create such conditions for the child to feel psychological protection, comfort, so often they lose parental authority, there is a conflict with the child because he / she does not obey "a weak" mother. The mother is in a very tense mental state and requires from the children the ability to give reasons, patience, mental balance, to make control over their feelings. The mother and the child, therefore, expect from each other what they cannot give each other. There is a reverse psychological effect: never before the mother has been so incapable of caring for the interests of the child as it is now. And never before, except for the first few years of the child's life, the child did not demand so much warmth from the mother. The dynamics of the crisis for many children after the divorce of his / her parents is based on such a contradiction. This leads to aggravating consequences of the child-parent relationships and the conclusion of it, to conflicts. As a result of a single-parent family children often start using psychoactive substances.

In some cases the mother, fearing that without the father she can't provide upbringing of the child in a rather right way, especially in the child's age of 14-17, she tries to play the role of a father, so she provides the upbringing of a child strictly, despotically, constantly monitoring his / her behavior. As a result of such upbringing there is often an aggressive aggravation of the relationships between a mother and a child, there is a danger of losing the mother's qualities in the eyes of the child, such as the ability "to feel» the child, to come for his / her help when he / she needs it. The mother's personal problems, because of which she treats the child in a different way, usually lead to the fact that the child in the psychological sense «loses» his / her mother. The mother's personality remains quite «achievable», a real one, but her best qualities seem to the child as «lost ones». 


\section{Conclusions}

Thus, children after divorce of his / her parents usually:

- react sharply to maternal irritation, perceive it as a complete inconvenience of life and lack of happiness, they are constantly in a state of emotional discomfort and anxiety;

- painfully experience the father's outcome and feel a state of cognitive dissonance, explaining the resentment in relations to the mother - usually not out of evil, but out of fear of losing her as a real friend;

- feel abandoned not only by the father, but also by the mother, who tries to provide her support for each usual way of life, to work more and to pay less attention to her children;

- sometimes suffering from excessive maternal care, when the mother tries to fill the deficit of parental love and care with exaggerated attention and caresses;

- suffering from neuroses, can not boast of good performance and discipline at school, envy «normal» children and are unable to communicate with them in the best way;

- are deprived because of the opportunity to develop their person, because they (especially boys) do not have an example of adequate male attitude to life or (if the father is an alcoholic and a «hooligan») have already mastered the usual pathological patterns of the behavior. All these reasons, in turn, can certainly lead to the fact that the child begins to use psychoactive substances.

The likelihood of maladaptation in a child-parent relationships during the post-divorce crisis depends on both the mother's and child's expectations of each other and many other circumstances.

It is during the period of maladaptation, for example, when the mother and the child are deprived of one of the possibilities of resolving conflict situations, which in a certain period of time were real, such as: facilitating the relationships through the intervention of the third person - an aunt, a grandmother and some others. As a rule, in this case, throughout the subse-

(C) Kompliienko Iryna

DOI (article): https://doi.org/10.32626/2227-6246.2020-50.104-126 
quent life of the existence of good and loving the third person helps to compensate for the joyless moments that take place in the relationships with the "other one»; this attitude greatly neutralizes the child's aggression and significantly eliminates the emergence of fear. In a family where a child takes psychoactive substances, the conflict with a mother or a father (or both of them) becomes extraordinary. In addition, the child's communication with the father is perceived by the mother as a situation of relief. But if the mother is divorced, then everything becomes much more complicated, and if the child, after arguing with her, suddenly tries to call the father, the mother may get very angry and shout at the child: "Well, go to live with your dad!» Emotionally agitated mothers usually do not understand what they are doing with this phrase, resorting to this kind of method as a struggle is; moreover, the child will feel defeated, and he / she feels a real satisfaction - his / her goal has been achieved. At the same time, the child begins to realize that the mother tells him / her to "get out», and the father is already almost have lost her, and then the mother says that she does not need the child at all. Thus, the child «is cornered", and he / she is in despair experiencing the hopelessness of this situation, feels anger towards the mother. Therefore, it is no coincidence that such children begin to look for another, important for them social micro-group, which leads to dependence on the use of psychoactive substances.

\section{Literature}

Буянов М. И. Ребенок из неблагополучной семьи: записки детского психиатра. Москва : Прогресс, 1988. 136 с.

Гарбузов В. И. Нервные дети: советы врача. Ленинград : Медицина. Ленинградское отделение; Москва : Ассоциативный совет книгоиздателей, 1990. 172 с.

Максименко С., Ткач Б., Литвинчук Л., Онуфрієва Л. Нейропсихолінгвістичне дослідження політичних гасел із зовнішньої реклами. Психолінгвістика. Психолингвистика. Psycholinguistics: Зб. наук. праць ДВНЗ «Переяслав-Хлельнищький пед. ун-т ілені Григорія Сковороди». Переяслав-Хмельницький : ФОП Домбровська Я. М., (C) Kompliienko Iryna

DOI (article): https://doi.org/10.32626/2227-6246.2020-50.104-126 
2019. Вип. 26 (1). С. 246-264. URL : https://psycholing-journal. com/index.php/journal/article/view/715.

Пожар Л. Психология аномальных детей и подростков. Патопсихология. Москва : Изд-во МГУ; Воронеж, 1996. 128 с.

Раттер М. Помощь трудным детям. Москва : Наука, 1978. 193 с.

Сатир В. Как строить себя и свою семью. Москва : Педагогика Пресс, 1992. $192 \mathrm{c}$.

Стегачёва С. В. Типы дезадаптивного поведения супружеских пар и их психологическая коррекция: дис. ... канд. психол. наук: 19.00.07. Тамбов, 2004. $145 \mathrm{c.}$

Mykhalchuk, N., \& Ivashkevych, Ed. (2018). Psycholinguistic features of the development of social intelligence of the teacher. Психолінгвістика. Психолингвистика. Psycholinguistics: Зб. наук. праць ДВНЗ «Переяслав-Хмельницький пед. ун-т імені Григорія Сковороди». Переяслав-Хмельницький : ФОП Домбровська Я. М. Вип. 23 (1). C. 242-257. DOI 10.5281 /zenodo.1211618.

Mykhalchuk, Nataliia, \& Onufriieva, Liana (2020). Psycholinguistic features of representation of emotions by the concept of «Fear». Проблеми сучасної психологї: Зб. наук. праць Кам'янеиь-Подільського національного університету ілені Івана Огієнка, Інституту психологї̈ ілені Г. С. Костюка НАПН України. Кам'янецьПодільський : ТOB «Друкарня «Рута». Вип. 48. С. 206-227. DOI https://doi.org/10.32626/2227-6246.2020-48.206-227

Tabachnikov, S., Pinchuk, I., Kharchenko, Ye., Chepurna, A., Zdoryk, I., \& Mykhalchuk, N. (2019). Criteria for diagnostics and treatment of somatic patients who use psychoactive substances in the practice of family medicine. Архів психіатрї̈: Наук.-пр. журнал. Т. 25, № 1 (96). C. 229-234. DOI https://doi.org/10.37822/2410-7484. 2019.25.1.15-21.

Tabachnikov, S., Pinchuk, I., Kharchenko, Ye., Osukhovskaia, E., Tabachnikov, O., Mazbits, V., Chepurna, A., Salden, V., Tovalovych, T., \& Mykhalchuk, N. (2018). Psychological, clinical and instrumental-laboratory methods for the diagnosis of the usage of psychoactive substances by somatic patients in the practice of family medicine. Apxis психіатрії : Наук.-пр. журнал. Т. 24, № 4 (95). С. 229-234. DOI https://doi.org/10.37822/24107484.2018.24.4.229-234.

\section{References}

Buianov, M. I. (1988). Rebenok iz neblagopoluchnoi semi: zapiski detskogo psikhiatra [A child from a dysfunctional family: notes of a children psychiatrist]. Moskva : Progress [in Russian].

(C) Kompliienko Iryna

DOI (article): https://doi.org/10.32626/2227-6246.2020-50.104-126 
DOI: https://doi.org/10.32626/2227-6246.2020-50

Garbuzov, V. I. (1990). Nervnyie deti: sovety vracha [Nervous children: doctor's advice]. Leningrad : Meditsina. Leningradskoie otdeleniie; Moskva : Assotsiativnyi sovet [in Russian].

Maksymenko, S., Tkach, B., Lytvynchuk, L., \& Onufriieva, L. (2019). Neiropsykholinhvistychne doslidzhennia politychnykh hasel iz zovnishnoi reklamy [A neuropsycholinguistic research of political slogans from outdoor advertising]. Psykholinhvistyka. Psikholingvistika. Psycholinguistics - Psycholinguistics. Psycholinguistics. Psycholinguistics: Collection of research papers of Pereiaslav-Khmelnytskyi Hryhoriy Skovoroda State Pedagogical University, 26 (1), 246-264. Pereiaslav-Khmelnytskyi : FOP Dombrovska Ya. M. Retrieved from https://psycholing-journal.com/index.php/journal/article/view/715 [in Ukrainian].

Pozhar, L. (1996). Psikhologiia anomalnykh detei i podrostkov. Patopsikhologiia [Psychology of abnormal children and adolescents. Pathopsychology]. Moskva : Izdatelstvo MGU; Voronezh [in Russian].

Ratter, M. (1978). Pomoshch trudnym detiam [Help for difficult children]. Moskva : Nauka [in Russian].

Satir, V. (1992). Kak stroit sebia $i$ svoiu semiu [How to build oneself and one's family]. Moskva : Pedagogika Press [in Russian].

Stegacheva, S. V. (2004). Tipy dezadaptivnogo povedeniia supruzheskikh par i ikh psikhologicheskaia korrektsiia [Types of maladaptive behavior of married couples and their psychological correction]. Candidate's thesis. Tambov [in Russian].

Mykhalchuk, N., \& Ivashkevych, E. (2018). Psycholinguistic features of the development of social intelligence of the teacher. Psykholinhvistyka. Psikholingvistika. Psycholinguistics - Psycholinguistics. Psycholinguistics. Psycholinguistics: Collection of research papers of Pereiaslav-Khmelnytskyi Hryhoriy Skovoroda State Pedagogical University, 23 (1), 242-257. Pereiaslav-Khmelnytskyi : FOP Dombrovska Ya. M. DOI 10.5281/zenodo.1211618.

Mykhalchuk, Nataliia, \& Onufriieva, Liana (2020). Psycholinguistic features of representation of emotions by the concept of «Fear». Problemy suchasnoi psykholohii - Problems of modern psychology: Collection of Research papers of Kamianets-Podilskyi National Ivan Ohiienko University, G. S. Kostiuk Institute of Psychology of the National Academy of Educational Sciences of Ukraine, 48, 206-227. Kamianets-Podilskyi : TOV «Drukarnia «Ruta». Retrieved from https://doi.org/10.32626/2227-6246.2020-48.206-227.

Tabachnikov, S., Pinchuk, I., Kharchenko, Ye., Chepurna, A., Zdoryk, I., \& Mykhalchuk, N. (2019). Criteria for diagnostics and treatment of (c) Kompliienko Iryna

DOI (article): https://doi.org/10.32626/2227-6246.2020-50.104-126 
somatic patients who use psychoactive substances in the practice of family medicine. Arkhiv psykhiatrii - Archives of Psychiatry: Scientific and Practical Journal, 25, 1 (96), 229-234. DOI https://doi. org/10.37822/2410-7484.2019.25.1.15-21.

Tabachnikov, S., Pinchuk, I., Kharchenko, Ye., Osukhovskaia, E., Tabachnikov, O., Mazbits, V., Chepurna, A., Salden, V., Tovalovych, T., \& Mykhalchuk, N. (2018). Psychological, clinical and instrumental-laboratory methods for the diagnosis of the usage of psychoactive substances by somatic patients in the practice of family medicine. Arkhiv psykhiatrii - Archives of Psychiatry: Scientific and Practical Journal, 24, 4 (95), 229-234. DOI https://doi.org/10.37822/ 24107484.2018.24.4.229-234.

Комплієнко Ірина. Причини конфліктів у взаємостосунках міњ батьками та дітьми

\section{АНОТАЦІЯ}

Мета статmі - дослідити проблему дезадаптивних сімейних взаємостосунків між батьками та школярами старшого шкільного віку, яка, як правило, характеризується гостротою конфлліктів, що виникли і супроводжуються блокуванням їх конструктивного розв'язання, загостренням внутрішньосімейного відчуження.

Для розв'язання поставлених у роботі завдань використано такі теоретичні методи дослідження: категоріальний, структурно-функціональний, аналіз, систематизація, моделювання, узагальнення. У якості емпіричних методів обрано методи анкетування й інтерв'ювання.

Результати дослідження. 3 метою з'ясування причин конфрліктів старшокласників із батьками нами було проведено пілотне дослідження на основі розробленої анкети «Причини конфліктів старшокласників із батьками». Анкету було проведено з 355 старшокласниками м. Києва, м. Рівного та м. Миколаєва. Показано, що з точки зору молоді конфллікти з батьками не є основною проблемою у цей віковий період. На основі опитування репрезентативної групи 16-річних старшокласників близько у третини з них (у 27\% школярок і у 29\% учнів чоловічої статі) встановлено наявність суперечок, неабиякі розбіжності у поглядах із батьками, неприйняття критики останніх. Визначено, що водночас лише деякі учні повністю відкидають погляди батьків, яких називають "старими» (8\% школярок і 13\% старшокласників чоловічої статі). Для 33\% школярок і

(C) Kompliienko Iryna

DOI (article): https://doi.org/10.32626/2227-6246.2020-50.104-126 
27\% учнів чоловічої статі критика і суперечки стосуються не всіх сфер життя, а, переважно, одягу, зачіски і присутності вечорами вдома. У старшокласників, які вживають психоактивні речовини, виявлено значно більше конфрліктних ситуацій, ніж у здорових. Зазначено, що суперечки з батьками є важливим негативним чинником, який обтяжує розвиток старшокласника (35\% респондентів чоловічої статі та 28\% - жіночої). Доведено, що, разом із цим, 26\% школярок і $31 \%$ учнів чоловічої статі вказали на те, що саме проблеми в навчанні призвели до вживання наркотиків, скоєння правопорушень, симптомів стресу і низької самооцінки.

Висновки. Визначено, що саме в період дезадаптивності мати і дитина позбавлені однієї з можливостей розв'язання конфліктних ситуацій, які у певний період часу були реальними, а саме: полегшення взаємостосунків завдяки втручанню третьої особи - тітки, бабусі тощо. Як правило, у такому випадку впродовж усього подальшого життя існування доброї й люблячої "третьої особи» допомагає компенсувати безрадісні хвилини, що мають місие у взаємостосунках з «іншим»; таке ставлення великою мірою нейтралізує агресивність дитини і суттєво нівелює виникнення страху. В сім'ї, де дитина вживає психоактивні речовини, конфллікт із матір'ю чи батьком (або з обома) набуває надзвичайних розмірів. Крім того, спілкування дитини з батьком мати сприймає як ситуацію полегшення. Але якщо мати - розлучена, то все стає набагато складніше, і якщо дитина, посварившись із нею, раптом намагається зателефонувати батькові, то мати може навіть розлютитися та крикнути на дитину: «Ну й забирайся до свого тата!». Емоційно схвильовані матері, як правило, не розуміють, що вони роблять цією фразою, вдаючись до подібних методів боротьби; більш того, дитина при цьому відчуває себе переможеною, а мати відчуває задоволення -ії мету досягнуто. Водночас дитина починає усвідомлювати, що мати каже їй «забиратися», а батько для неї вже і без того є майже втраченим, а тут ще й мама каже, що дитина їй зовсім не потрібна. Отже, дитина виявляється "загнаною в кут", і вона у відчаї переживає всю безвихідність свого становища, відчуває до матері злість. Тому не випадково такі діти починають шукати іншу, значущу для них соціальну мікрогрупу, що призводить до залежності від вживання психоактивних речовин.

Ключові слова: дезадаптивні сімейні взаємостосунки, конфллікти, неконструктивне розв'язання, загострення внутрішньосімейного відчуження, причини конфрліктів, агресія, страх, психоактивні речовини.

(c) Kompliienko Iryna

DOI (article): https://doi.org/10.32626/2227-6246.2020-50.104-126 
Комплиенко Ирина. Причины конфликтов во взаимоотношениях между родителями и детьми

\section{АННОТАЦИЯ}

Цель статьи - исследовать проблему дезадаптивных семейных взаимоотношений между родителями и школьниками старшего школьного возраста, которая, как правило, характеризуется остротой конфликтов, возникших и сопровождающихся блокировкой их конструктивного решения, обострением внутрисемейного отчуждения.

Для решения поставленных в работе задач использованы следующие теоретические методы исследования: категориальный, структурно-функциональный, анализ, систематизация, моделирование, обобщение. В качестве эмпирических методов использованы методы анкетирования и интервьюирования.

Результаты исследования. С целью выяснения причин конфрликтов старшеклассников с родителями нами было проведено пилотное исследование на основе разработанной анкеты «Причины конфрликтов старшеклассников с родителями». Анкету было проведено с $355 \mathrm{cmap}$ шеклассниками г. Киева, г. Ровно и г. Николаева. Показано, что с точки зрения молодежи конфлликты с родителями не являются основной проблемой в данный возрастной период. На основе опроса репрезентативной группы 16-летних старшеклассников примерно у трети из них (у 27\% школьниц и у 29\% учащихся мужского пола) установлено наличие споров, незаурядные разногласия с родителями, неприятие критики последних. Определено, что в то же время лишь немногие ученики полностью отвергают точку зрения родителей, которых называют "старыми» (8\% школьниц и 13\% старшеклассников мужского пола). Для 33\% школьниц и 27\% учащихся мужского пола критика и споры касаются не всех сфер жизни, а, главным образом, одежды, прически и присутствия по вечерам дома. У старшеклассников, употребляющих психоактивные вещества, обнаружено значительно больше конфликтных ситуаций, чем у здоровых детей их возраста. Указано, что споры с родителями являются важным негативным фактором, который отягощает развитие старшеклассника (35\% респондентов мужского пола и 28\% - женского). Доказано, что, наряду с этим, 26\% школьниц и 31\% учащихся мужского пола отметили то, что именно проблемы в обучении привели к употреблению ими наркотиков, совершению правонарушений, симптомам стресса и низкой самооценке.

(C) Kompliienko Iryna

DOI (article): https://doi.org/10.32626/2227-6246.2020-50.104-126 
Выводы. Определено, что именно в период дезадаптивности мать и ребенок лишены возможностей конструктивного решения конфрликтных ситуаций, которые в определенный период времени были реальными, а именно: облегчение взаимоотношений благодаря вмешательству третьего лица - тети, бабушки и др. Как правило, в таком случае в течение всей последующей жизни существованием доброго и любящего "третьего лица» были компенсированы безрадостные минуты, имеющие место во взаимоотношениях с "другим»; такое отношение во многом нейтрализовало агрессивность ребенка и существенно нивелировало возникновение у него страха. В семье, где ребенок употребляет психоактивные вещества, конфликт с матерью или отиом (или с обоими) приобретает чрезвычайные размеры. Кроме того, общение ребенка с отиом мать воспринимает как ситуацию облегчения. Но если мать - в разводе, то все становится гораздо сложнее, и если ребенок, поссорившись с ней, вдруг пытается позвонить отиу, то мать может и вовсе разозлиться и крикнуть на ребенка: «Ну и убирайся к своему папе!». Эмоционально взволнованные матери, как правило, не понимают, что они делают этой фразой, прибегая к подобным методам борьбы; более того, ребенок при этом чувствует себя побежденным, а мать испытывает удовольствие - ее цель достигнута. В то же время ребенок начинает осознавать, что мать говорит ему "убираться», а отец для него уже и без того почти потерян, а тут еще и мать говорит, что ребенок ей совсем не нужен. Таким образом, ребенок оказывается "загнанным в угол", и он в отчаянии переживает всю безысходность своего положения, испытывает к матери злость или агрессию. Не случайно такие дети начинают искать другую, значимую для них социальную микрогруппу, что приводит к зависимости от употребления психоактивных веществ.

Ключевые слова: дезадаптивные семейные взаимоотношения, конфлликты, неконструктивное решение, обострение внутрисемейного отчуждения, причины конфликтов, агрессия, страх, психоактивные вещества.

Original manuscript received June 14, 2020

Revised manuscript accepted July 27, 2020

(C) Kompliienko Iryna

DOI (article): https://doi.org/10.32626/2227-6246.2020-50.104-126 